\title{
An Addiction Detection Application Playing Free Fire Games Based on Android Using Tsukamoto's Fuzzy Logic
}

\section{Aplikasi Pendeteksi Kecanduan Bermain Game Free Fire Berbasis Android Dengan Menggunakan Logika Fuzzy Tsukamoto}

\author{
$1^{\text {st }}$ Hasan Basri ${ }^{1}, 2^{\text {nd }}$ Mochamad Alfan Rosyid ${ }^{2}$ \\ \{hasan.hb488@gmail.com ${ }^{1}$, alfanrosyid@umsida.ac.id ${ }^{2}$ \}
}

Universitas Muhammadiyah Sidoarjo ${ }^{1,2}$

\begin{abstract}
Online games that have a battle royal genre nowadays are very much the inantantnya. One of them is Free Fire which has been downloaded by more than 100 million people. The high number indicates that a person's high interest in playing online games can have a negative impact on one of them. For that, there is an app that can detect how much fun a person has in playing Free Fire games. By utilizing the fuzzy logic method tsukamoto allows it to detect the level of addiction of a person which is an android-based application. By utilizing the data owned by each player as an input variable that will produce output in the form of an addiction level percentage. Based on the result of the test carrieed out, the precentageresult were $83.34 \%$ which indicated a good category. Utilization of fuzzy tsukamoto method is expected to provide the right conclusions and in accordance with the expected.
\end{abstract}

Keywords - Addiction; Online Games; Free Fire; Tsukamoto Fuzzy Logic

\begin{abstract}
Abstrak. Game online yang mempunyai genre battle royal saat ini sangatlah banyak peminantnya. Salah satunya yaitu Free Fire yang mana sudah diunduh oleh lebih dari 100 juta orang. Tingginya angka tersebut menunjukkan bahwa tingginya minat seseorang dalam memainkan game online, sehingga dapat menimbulkan dampak negatif yaitu salahsatunya kecanduan. Untuk itu diperlukan adanya sebuah aplikasi yang bisa mendeteksi seberapa tingkat kecandauan seseorang dalam bermain game Free Fire. Dengan memanfaatkan metode logika fuzzy tsukamoto memungkinkan dapat mendeteksi tingkat kecanduan seseorang yang mana aplikasi tersebut berupa aplikasi yang berbasis android. Dengan memanfaatkan data yang dimiliki oleh setiap pemain sebagi variabel input yang akan menghasilkan output berupa presentase tingkat kecanduan. Berdasarkan hasil pengujian yang dilakukan didapatkan hasil presentase yaitu 83,34\% yang menunjukkan kategori baik. Pemanfaatan metode fuzzy tsukamoto diharapkan dapat memberikan kesimpulan yang tepat dan sesuai dengan yang diharapkan.
\end{abstract}

Kata Kunci - Kecanduan; Game Online; Free Fire; Logika Fuzzy Tsukamoto

\section{Pendahuluan}

Berbagai macam media hiburan seperti game online saat ini sangatlah mudah diakses secara bebas. Saat ini permainan yang diakses menggunakan internet sangatlah banyak digunakan oleh masyarakat baik kalangan anakanak, remaja maupun tua. Pada dasarnya game hanya digunakan untuk mengisi waktu-waktu kosong juga menghilanghkan kebosanan terutama game online. Padahal kenyataannya terlalu banyak bermain game menjadikan pemain kecanduan untuk memperbanyak waktu bermain game. Seringnya bermain game yang membuat seseorang kecanduan untuk memainkannya terus menerus juga berdampak pada tingkah laku seseorang. Menurutt sumber dari detik.com kecanduan game ditetapkan sebagai gangguan mental oleh World Health Organization (WHO) [1]. Kecanduan game termasuk dalam International Statistical Classification of Diseases and Related Health Problem (ICD-11), ICD merupakan daftar penyakit, gejala, tanda dan penyebab yang dikeluarkan oleh PBB [2].

Oleh karena itu diperlukan adanya sebuah sistem yang dirancang untuk mendeteksi dini seberapa besar tingkat kecanduan seseorang dalam bermain game online salah satunya yaitu FREE FIRE.FREE FIRE merupakan game bergenre battle royal yang menempati uruutan pertama dalam pupularitasnya baik bagi pengguna android maupun ios. Menurut cnbcindonesia.com jumlah pemain aktif FREE FIRE secara harian sudah tembus 80 juta pengguna. dengan memanfaatkan beberapa data-data pemain dalam bermain game. Dalam perancangan ini metode yang digunakan adalah fuzzy tsukomoto, dimana metode fuzzy tsukomoto ini bisa mendeteksi seberapa besar tingkat kecanduan bermain game dari data - data yang diinputkan oleh pengguna berdasarkan profil setiap pemain yang menghasilkan output presentase tingkat kecanduan seseorang mulai dari rendah sampai tinggi.

Beberapa penelitian terdahulu menyatakan bahwa penerapan logika fuzzy metode mamdani untuk mebuat sistem pendeteksi dini akan kecanduan semartphone yang dapat mengganggu terhadap tingkat produktifitas kerja sangat membantu sesorang dalam menganalisis seberapa tingkat kecanduan seseorang akan menggunakan smartphone [3]. Sedangkan menurut Ericksan Siantury dalam penelitianya yang menggunakan metode Certainty Factor untuk mendiagnosa gejala-gejala kecanduan game online menjadikannya pilihan yang tepat digunakan dalam sitem pakar karena dengan menggunakan metode ini sistem yang dirancang dapat dengan mudah dipahami [4]. Dari beberapa 
penelitian diatas menunjukkan bahwa ketidaksamaan metode dan hasil penelitian dapat disebabkan oleh perbedaan pemahaman dan perkembangan teknologi yang menjadikan setiap orang dapat memilih berbagai macam metode untuk menerapkan logika fuzzy sebagai alat pendeteksi dini tinghkat kecanduan.

Penelitian ini tertuju pada objek para pemain game FREE FIRE. Pemilihan game ini berdasarkan pengamatan yang dilakukan oleh peneliti yang menyimpulkan bahwa game FREE FIRE saat ini merupakan salah satu game online yang sangat laris dikalangan masyarkat mulai dari yang muda hingga tua bahkan anak-anak sekalipun.

\section{METODE}

\section{A. Metode Pengumpulan Data}

Free fire merupakan game online yang bergenre battleroyal. Setiap permainan dalam Garena Free Fire berisikan 50 pemain yang terdampar di pulau terpencil di mana setiap pemain bebas memilih posisi untuk memulai pemainan menggunakan parasut. Mereka bermain mulai dari menembak dengan senjata, menyetir kendaraan untuk menjelajahi map yang besar, bersembunyi dalam terowongan, atau bahkan menjadi tidak terlihat dengan tiarap di padang rumput. Semua ini mereka lakukan dengan tujuan utama, yakni bertahan hidup [5].

Teknik pengumpulan data yang dilakukan dalam penelitian ini adalah melalui peringkat dalam game Free Fire nerdasarkan tingkat Regional. Setiap data peringkat yang muncul hanya ada 50 data pemain. Berdasarkan hasil observasi yang dilakukan data yang berhasil didapatkan guna untuk mendukung proses analisa tingkat kecanduan bermain game Free Fire yaitu 3 data, diantaranya.

1. Jumlah Permainan

Jumlah permainan merupakan riwayat dari pemain tersebut selama bermain free fire baik itu solo atau bermain sendiri, duo atau bermain berdua maupun bemain squad atau dalam mode grup. Dari tiga mode tersebut nantinya akan dijumlahkan menjadi satu yang nantinya jumlah tersebut akan dijadikan sebagai variabel input.

2. Jumlah Win

Jumlah win sama saja dengan jumlah permainan dan jumlah kill. Namun disini bukan seberapa banyak pemain tersebut memainkan game tersebut ataupun seberapa banyak korban yang didapatkan melainkan jumlah kemenangan dari seluruh permainan yang dimainkannya baik itu solo atau bermain sendiri, duo atau bermain berdua maupun bemain squad atau dalam mode grup. Dari tiga mode tersebut nantinya juga akan dijumlahkan menjadi satu yang nantinya jumlah tersebut akan dijadikan sebagai variabel input.

3. Jumlah Kill

Jumlah kill sama saja dengan jumlah permain. Namun disini bukan seberapa banyak pemain tersebut memainkan game tersebut melainkan jumlah korban dari seluruh permainan yang dimainkannya baik itu solo atau bermain sendiri, duo atau bermain berdua maupun bemain squad atau dalam mode grup. Dari tiga mode tersebut nantinya juga akan dijumlahkan menjadi satu yang nantinya jumlah tersebut akan dijadikan sebagai variabel input.

\section{B. Pengembangan Sistem}

Dalam melakukan pengembangan sistem ini metode yang digunakan adalah waterfall. Proses metode waterfall merupakan pengerjaan dari suatu sistem yang dilakukan secara berurutan [6]. Tahapan dari metode waterfall yaitu sebagai berikut :

1. Analisis Kebutuhan

Pada tahap yang awal yakni analisis kebutuhan dilakukan dengan menganalisa kebutuhan pengguna dan pembuat perangkat lunak, diantaranya :

A. Perangakat lunak (Software)

Perangkat lunak yang dibutuhkan dalam membangun aplikasi ini adalah :

1. Windows 10 sebagai sistem operasi pada perangkat komputer.

2. Android Oreo sebagai sistem operasi pada perangkat android serta sebagai emulator.

3. android Studio

4. JavaMicrososoft Office 2013

5. Mockplus sebagai media desain aplikasi.

6. Draw.io sebagai perangcangan sistem

B. Perangkat keras

Perangkat keras yang dibutuhkan untuk membangun aplikasi tersebut adalah sebagai berikut :

1. Laptop Samsung 270E.

2. Prosesor Intel Core i3.

3. RAM DDR4 4GB.

4. HDD 1 Terra.

5. Perangkat android Xiaomi Redmi 5+. 
C. Brainware

Brainware dari aplikasi yang akan diusulkan adalah pelakasana personal

2. Desain Sistem

Pada tahapan ini memiliki tujuan untuk penggambaran dari sistem yang akan dibuat. Desain sistem yang akan dibuat meliputi :

a. Use case Diagram

b. Activity Diagram

c. Flowchart

d. Perancangan User Interface (UI)

3. Penulisan Kode Program

Pada tahap ini merupakan implementasi dari tahap analisis sampai perancangan dan hasil perancangan sistem kedalam kode program yang mana hal ini sistem yang akan dibuat berupa aplikasi berbasis android yang menngunakan bahasa pemrograma Java dan XML.

4. Pengujian Program

Setelah proses pembuatan perangkat lunak selesai maka diperlukan adanya pengujian untuk memastikan sistem yang dibuat sudah berfungsi dengan benar dan dapat digunakan tanpa ada kesalahan.

5. Pemeliharaan

Tahap ini merupakan tahapan yang paling akhir dari metode waterfall. Setelah semua tahapan selesai mka dalam hal ini diperlukan adanya pemeliharaan agar menjaga performa serta kualitas dari sistem tersebut.

\section{Metode Analisis Fuzzy Tsukamoto}

Logika Fuzzy adalah suatu suatu proses pengambilan keputusan berbasis aturan yang bertujuan untuk memecahkan masalah, dimana sistem tersebut sulit untuk dimodelkan dan ketidakjelasan [7]. Terdapat 3 tahapan dalam metode logika fuzzy :

1. Idendtifikasi Variabel

Berdasarkan identifikasi yang dilkukan didapatkan 4 variabel yakni 3 variabel input yaitu jumlah permainan, jumlah win, jumlah kill, dan 1 variabel output yang berupa tingkat kecanduan.

2. Pembentukan Himpunan Fuzzy

Setiap himpunan fuzzy mempunyai batasan nilai tersendiri yang mana untuk menentukan nilai tersebut menggunakan rumus kuartil dan median. Akan tetapi sebelum itu data yang sudah terkumpul diurutkan terlebih dahulu mulai dari yang terkecil sampai terbesar. Nilai pada himpunan fuzzy diperoleh dari kuartil bawah (Q1), median (Q2), dan kuartil atas (Q3) sebagai variabel input. Berdasarkan data diatas banyaknya data berjumlah 24. Data tersebut berjumlah genap, maka habis dibagi 4 sehingga menggunakan rumus sebagai berikut [8].

$$
\begin{aligned}
\mathrm{Q} 1 & =\frac{\mathrm{X}_{(24 / 4)}+\mathrm{X}_{((24 / 4)+1)}}{2} \\
& =\frac{\mathrm{X}_{6}+\mathrm{X}_{7}}{2} \\
\mathrm{Q} 2 & =\frac{\mathrm{X}_{(24 / 2)}+\mathrm{X}_{((24 / 2)+1)}}{2} \\
& =\frac{\mathrm{X}_{12}+\mathrm{X}_{13}}{2} \\
\mathrm{Q} 3 & =\frac{\mathrm{X}_{(3.24 / 4)}+\mathrm{X}_{(3.24 / 4+1)}}{2} \\
& =\frac{\mathrm{X}_{18}+\mathrm{X}_{19}}{2}
\end{aligned}
$$

Berdasarkan perhitungan diatas maka dapat di tentukan nilai himpunan fuzzy pada tiap varabel dengan kategori sedikit, sedang dan banyak. Berikut disajikan dalam tabel dibawah.

Tabel 1. Himpunan Fuzzy Input

\begin{tabular}{cccc}
\hline No & Variabel & Kategori & Nilai \\
\hline \multirow{2}{*}{$\mathbf{1}$} & Jumlah Permainan & Sedikit & $<2303$ \\
& & Sedang & $1294-4284$ \\
& & Banyak & $>2303$ \\
$\mathbf{2}$ & Jumlah Win & Sedikit & $<209$ \\
& & Sedang & $104-364$ \\
& & & $>209$
\end{tabular}




\begin{tabular}{|c|c|c|c|}
\hline \multirow{3}{*}{3} & \multirow[b]{2}{*}{ Jumlah Kill } & Sedikit & $0-4357$ \\
\hline & & Sedang & $1650-6539$ \\
\hline & & Banyak & $>4357$ \\
\hline
\end{tabular}

Sedangkan untuk variabel output yang berupa tingkat kecanduan,. berdasarkan penelitian yang dilakukan oleh Ayu Permata .S tingkat kecanduan dapat dibagi menjadi 3 kategori yakni rendah, sedamg dan tinggi [9]. Berikut disajikan dalam bentuk tabel :

Tabel 2 Himpunan Fuzzy Output

\begin{tabular}{ccc}
\hline No & Nilai & Himpunan Fuzzy \\
\hline $\mathbf{1}$ & $>36$ & Rendah \\
$\mathbf{2}$ & $36-67$ & Sedang \\
$\mathbf{3}$ & $>67$ & Tinggi \\
\hline
\end{tabular}

3. Aturan Fuzzy (Rules)

Fungsi basis atau biasa disebut dengan rule base digunkan untuk merelasikan dua variabel atau lebih pada logika fuzzy. Basis aturan ini berisi beberapa aturan yang berupa IF-THEN. IF disebut dengan anteseden dan THEN disebut dengan konsekuen. Berdasarkan uraian sebelumnya terdapat 3 variabel yang menjadi anteseden atau IF diantaranya:

a. Variabel jumlah permainan.

b. Variabel jumlah win.

c. Variabel jumlah kill

Sedangkan variabel yang menjadi konsekuen atau THEN yaitu variabel kecanduan. Dari uraian diatas menandakan bahwa ada $3^{3}=27$ kombinasi rule yang akan digunakan untuk menentukan nilai dari konsekuensinya. Berikut tabel kombinasi rule base yang akan muncul:

Tabel 3. Rule

\begin{tabular}{lcccc}
\hline Aturan & $\begin{array}{c}\text { Jumlah } \\
\text { Permainan }\end{array}$ & $\begin{array}{c}\text { Jumlah } \\
\text { Win }\end{array}$ & $\begin{array}{c}\text { Jumlah } \\
\text { Kill }\end{array}$ & Kecanduan \\
\hline Rule 1 & Sedikit & Sedikit & Sedikit & Rendah \\
Rule 2 & Sedikit & Sedikit & Sedang & Rendah \\
Rule 3 & Sedikit & Sedikit & Banyak & Rendah \\
Rule 4 & Sedang & Sedang & Sedikit & Sedang \\
Rule 5 & Sedang & Sedang & Banyak & Sedang \\
Rule 6 & Sedang & Sedang & Sedang & Sedang \\
Rule 7 & Banyak & Banyak & Banyak & Tinggi \\
Rule 8 & Banyak & Banyak & Sedang & Tinggi \\
Rule 9 & Banyak & Banyak & Sedikit & Tinggi \\
Rule 10 & Sedikit & Sedang & Sedikit & Rendah \\
Rule 11 & Sedikit & Banyak & Sedikit & Rendah \\
Rule 12 & Sedang & Sedikit & Sedang & Sedang \\
Rule 13 & Sedang & Banyak & Sedang & Sedang \\
Rule 14 & Banyak & Sedang & Banyak & Tinggi \\
Rule 15 & Banyak & Sedikit & Banyak & Tinggi \\
Rule 16 & Sedikit & Sedang & Sedang & Sedang \\
Rule 17 & Sedikit & Banyak & Banyak & Tinggi \\
Rule 18 & Sedang & Sedikit & Sedikit & Rendah \\
Rule 19 & Sedang & Banyak & Banyak & Tinggi \\
& & & & \\
\hline
\end{tabular}


Procedia of Engineering and Life Science Vol. 1. No. 2 Juni 2021

Seminar Nasional \& Call Paper Fakultas Sains dan Teknologi (SENASAINS 2nd)

Universitas Muhammadiyah Sidoarjo

\begin{tabular}{rrrrl} 
Rule 20 & Banyak & Sedang & Sedang & Sedang \\
Rule 21 & Banyak & Sedikit & Sedikit & Rendah \\
Rule 22 & Sedang & Sedikit & Banyak & Sedang \\
Rule 23 & Sedang & Banyak & Sedikit & Sedang \\
Rule 24 & Banyak & Sedikit & Sedang & Sedang \\
Rule 25 & Banyak & Sedang & Sedikit & Sedang \\
Rule 26 & Sedikit & Banyak & Sedang & Sedang \\
Rule 27 & Sedikit & Sedang & Banyak & Sedang \\
\cline { 2 - 5 } & & & \\
4. Pefuzzyfikasi \\
Proses Defuzzyfikasi atau penegasan adalah tahap paling akhir dalam penghitungan, yakni untuk \\
memeproleh himpunan tegas. Hasil fuzzy nyata tidak dapat digunakan untuk sebuah aplikasi. Untuk itu perlu \\
dikonversikan terlebih dahulu kedalam jumlah himpunan tegas dengan menggunkan cara defuzzyfikasi Hasil \\
akhirnya diperoleh dengan menggunakan rata-rata terbobot [10].
\end{tabular}

\section{HaSil dan Pembahasan}

\section{A. Implementasi Tampilan Aplikasi}

Berdasarkan pengumpulan data yang dilakukan untuk perancangan Aplikasi Pendeteksi Tingkat Kecanduan Bermain Game Free Fire Berbasis Android. Maka diapatkan 5 Activity yaitu : Activity Splash Screen, Activity Form Input Data, Activity Hasil Diagnosa, Activity Tutorial, Activity Profile. Berikut tampilan dari activity tersebut:

1. Activity Splash Screen

Activity ini merupakan tampilan tambahan yang mucul ketika pertama kali membuka aplikasi. Activity ini hanya menjadi proses loading ketika akan masuk ke activity utama.

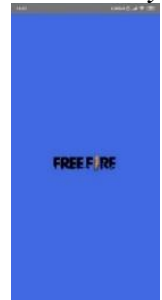

Gambar 1 Activity Splash Screen

2. Activity Form Input Data

Activity ini merupakan actiivity utama dari aplikasi yang dibuat. Pada activity ini akan ditampilkan 3 buah from input yang mana berisi input jumlah permainan, jumlah win, dan jumlah kill. Pada toolbar bagian atas terdapat juga option menu yang mana ketika di klik makan akan tampil 2 buah menu yaitu profile dan help.

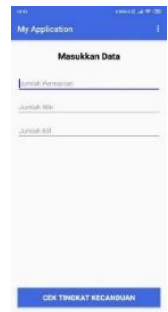

Gambar 2 Tampilan Form Input Data

3. Activity Hasil Diagnosa

Pada activity hasil diagnosa akan ditampilkan 4 buah textview yaitu texview nilai hasil tingkat kecanduan yang didapatkan dari pengitungan nilai yang diinputkan, textview Tingkat Kecanduan, textview hasil dari tingkat kecanduan yitu antara rendah, sedang dan tinggi , dan texview yang berupa solusi perdasarkan tingkat kecanduan yang dihasilkan. Pada icon dipojok kiri atas berfungsi untuk kembali kehalaman utama. Icon ini sama saja dengan tombol kembali pada smartphone. Activity ini akan mucul ketika pengguna sudah menginputka data 


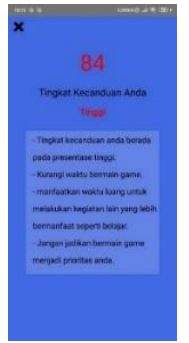

Gambar 3 Tampilan Hasil Diagnosa

4. Activity Tutorial

Pada activity ini akan akan ditampilkan cara-cara mencari data dari setiap pemain jika merasa kesulitan ketika mencari data yang diinputkan.

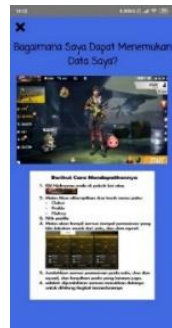

Gambar 4 Tampilan Tutorial

5. Activity Profile

Pada activity profil akan ditampilkan foto, nama, nim, judul, sedikit tentang aplikasi tersebut serta nama kampus.

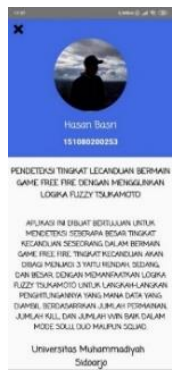

Gambar 5 Tampilan Profile

\section{B. Pengujian Aplikasi}

Pada pengujian aplikasi ini berkaitan dengan data yang dikumpulkan dari beberapa pemain Free Fire. Tujuan dari pengujian aplikasi ini adalah untuk membuktikan sejauh mana aplikasi berjalan dengan sempurna serta membandingkan antara penghitungan manual dengan penghitungan menggunakan aplikasi. Dari pengujian yang dilakukan oleh 24 pemain, 9 pemain berada ditingkat kecanduan rendah, 7 pemain berada ditingkat kecanduan sedang, dan 8 pemain berada ditingkat kecanduan Tinggi. Dengan menggunakan rumus sebagai berikut

1. Data Pemain Pertama

$\begin{array}{ll}\text { Nama } & =\# \$ @[\text { Suhel }] \\ \text { Jumlah permainan } & =1970 \\ \text { Jumlah Win } & =106 \\ \text { Jumlah Kill } & =2602\end{array}$

a. Mencari nilai keanggotaan tiap variabel

Jumlah Permainan Sedikit $=2303-1970 / 2303-1294=0,330029732$

Jumlah Permainan Sedang = 1970-1294 / 2303-1294 = 0,669970268

Jumlah Win Sedikit $=209-106 / 209-104=0,980952381$

Jumlah Win Sedang = 106-104 / 209-104 = 0,019047619

Jumlah Kill Sedikit $=4357-2602 / 4357-1650=0,648319173$

Jumlah Kill Sedang = 2602-1650 / 4357-1650 = 0,351680827

b. Mencari nilai z pada tiap aturan dengan menggunakan fungsi Min

\section{- Aturan 1}


Procedia of Engineering and Life Science Vol. 1. No. 2 Juni 2021

Seminar Nasional \& Call Paper Fakultas Sains dan Teknologi (SENASAINS $2^{\text {nd }}$ )

Universitas Muhammadiyah Sidoarjo

IF Jumlah Permainan Sedikit AND Jumlah Win Sedikit AND Jumlah Kill Sedikit THEN

Kecanduan Rendah

Predikat $1=\min (\mu$ jumlah permainanSEDIKIT [1970],

$\mu$ jumlah winsSEDIKIT [106],

$\mu$ jumlah killSEDIKIT [2602]

$=\min (0,330029732 ; 0,980952381 ; 0,351680827)$

$=0,980952381$

Himpunan Kecanduan RENDAH

\begin{tabular}{|c|c|}
\hline $36-Z / 15$ & $=0,980952381$ \\
\hline $0,980952381 \times 15$ & $=36-\mathrm{Z}$ \\
\hline 14,7142857 & $=36-\mathrm{Z}$ \\
\hline $\mathrm{Z}$ & $=36-14,7142857$ \\
\hline Z & $=21,2857143$ \\
\hline
\end{tabular}

- $\quad$ Aturan 2

IF Jumlah Permainan Sedang AND Jumlah Win Sedang AND Jumlah Kill Sedang THEN Tingkat kecanduan Sedang.

$\mu$ Predikat2 $=\mu$ permainanSEDANG $\cap \mu$ winSEDANG

$\bigcap \mu$ killSEDANG

$=\min (\mu j u m l a h$ permainanSEDANG [1970],

$\mu$ winsSEDANG [106], $\mu$ killSEDANG [2602]

$=\min (0,669970268 ; 0,019047619 ; 0,351680827)$

$=0,669970268$

Himpunan Kecanduan SEDANG

$$
\begin{array}{ll}
\mathrm{Z}-36 / 16 & =0,669970268 \\
0,669970268 \times 16 & =\mathrm{Z}-36 \\
10,7152429 & =\mathrm{Z}-36 \\
\mathrm{Z} & =36+10,7152429 \\
\mathrm{Z} & =46,7195243
\end{array}
$$

c. Defuzzyfikasi

$$
\begin{aligned}
Z & \left.=\frac{(0,980952381 \times 21,2857143)+(0,669970268 \times 46,7195243)}{0,980952381+0,669970268}\right) \\
& =, 52,1809643 / 1,65092265 \\
& =31,607157
\end{aligned}
$$

Berdasarkan hasil perhitungan diatas maka hasil yang diperoleh adalah 31,607157 yang menunjukkan bahwa tingkat kecanduan Rendah.. Sedangkan hasil perhitungan dari aplikasi sebagai baerikut :

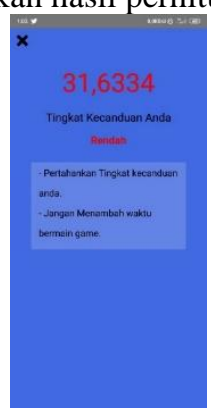

Gambar 6 Hasil Dari Data Pertama

\section{KESIMPULAN}

Berdasarkan penelitian yang telah dilakukan dalam merancang dan menyusun aplikasi, maka dapat diambil kesimpulan bahwa aplikasi telah selesai disusun dan dapat berjalan dengan lancar sesuai dengan rencana sebelumnya. Dengan memanfaatkan metode logika fuzzy tsukamoto pada aplikasi, pengguna bisa mengetahui tingkat kecanduannya. Serta aplikasi ini dapat menampilkan tingkat kecanduan berdasarkan dari data pemain yang diinputkan. 


\section{UCAPAN TERIMA KASIH}

Dalam hal ini peneliti menyampaikan perhargaan dan terimakasih yang sebesar-besarnya kepada kedua orang tua penulis atas perhatian, do'a, dukungan serta teman-teman yang selalu memberikan semangat, motivasi, dan dukungan kepada penulis,serta berbagai pihak yang tidak dapat disebutkan satu per satu yang telah membantu penulis dalam menyelesaikan artikel ilmiah.

\section{REFERENSI}

[1] Jati, A.S, "Kecanduan Game Ditetapkan sebagai Gangguan Mental”. 27 Mei 2019 13:29. [Online]. https://inet.detik.com/games-news/d-4566628/kecanduan-game-ditetapkan-sebagai-gangguan-mental. [Diakses 25 Maret 2020].

[2] Kemenkes. "Kecanduan Game Adalah Gangguan Perilaku". 23 Juni $20118 . \quad$ [Online]. https://www.kemkes.go.id/article/view/18062500003/ministry-of-health-game-addiction-is-behaviordisorder.html . [Diakses 25 Maret 2020].

[3] Aranski, Alvendo Wahyu and Rizki, Sestri Novi, "Pemograman Visual Basic Pendeteksi Dini Kecanduan Pengguna Smartphone Terhadap Produktivitas Kerja Menggunakan Logika Fuzzy”. Prosiding Seminar Nasional Ilmu Sosial dan Teknologi (SNISTEK), [S.1.], n. 1, p. 13-18, Oktober 2018. [Online]. Available: http://ejournal.upbatam.ac.id/index.php/prosiding/article/view/736. [ Diakses 29 Maret 2020].

[4] Siantury, Ericksan, "Sistem Pakar Diagnosa Gejala Kecanduan Game Online Dengan Menggunakan Metode Certainty Factor", Vol. VII, No 3, Agustus 2014.

[5] Garena. "Garena Free Fire" [Online]. https://turnamen.ff.garena.co.id/tentang/ . Diakses 20 September 2020.

[6] I . R. I. Astutik and I. Widiaty, "Integrated Management Information System for Curriculum in University" IOP Conf. Ser. Mater. Sci. Eng., vol. 384, p. 012077, Jul. 2018

[7] Kusumadewi, S dan Purnomo, H. (2004), “Aplikasi Logika Fuzzy Untuk Sistem Pendukung Keputusan Edisi Pertama", Graha Ilmu, Yogyakarta.

[8] Hapis .A (2017). "Penerapan Logika Fuzzy dengan Metode Tsukamoto untuk Mengestimasi Curah Hujan”. Skripsi. Universitas Maulana Malik Ibrahim Malang. Malang

[9] S. Ayu Permata , Tingkat Kecanduan Internet Pada Remaja Awal.s JPPI Vol 3 No 2, 2017, hlm 110-117. [Online]. doi : https://doi.org/10.29210/02018190. [Diakses 30 Maret 2020].

[10] Kusumadewi, S. (2003), Artificial Intelligence: Teknik dan Aplikasinya, Graha Ilmu, Yogyakarta. 